\title{
A palaeoparasitological analysis of rodent coprolites from the Cueva Huenul 1 archaeological site in Patagonia (Argentina)
}

\author{
María Ornela Beltrame ${ }^{1,3 /+}$, Norma Haydée Sardella1,3, \\ Martín Horacio Fugassa ${ }^{1,3}$, Ramiro Barberena ${ }^{2,3}$ \\ 'Laboratorio de Paleoparasitología y Arqueología Contextual, Departamento de Biología, Facultad de Ciencias Exactas y Naturales, \\ Universidad Nacional de Mar del Plata, Funes 3250, 7600 Mar del Plata, Buenos Aires, Argentina \\ ${ }^{2}$ Laboratorio de Geoarqueología, Facultad de Filosofía y Letras, Universidad Nacional de Cuyo, Mendoza, Argentina \\ ${ }^{3}$ Consejo Nacional de Investigaciones Científicas y Técnicas, Buenos Aires, Argentina
}

The aim of the present study was to examine the parasite fauna present in rodent coprolites collected from Cueva Huenul 1 (CH1), northern Neuquén (Patagonia, Argentina), an archaeological site that provides stratified sequences of archaeological and palaeontological remains dating from the Late Pleistocene/Early Holocene Transition to the Late Holocene period. Twenty rodent coprolites collected from different sedimentary units from the site, with ages ranging from 13.844 $\pm 75-1.416 \pm 37$ years BP, were examined for parasites. Each coprolite was processed as a whole: rehydrated, homogenised, spontaneously sedimented and examined using light microscopy. The coprolites and the eggs of any parasites present were described, measured and photographed. In all, 158 parasite eggs were found in 10 coprolites. The faeces were positive for Viscachataenia quadrata Denegri, Dopchiz, Elissondo \& Beveridge and Monoecocestus sp. Beddard (Cestoda: Anoplocephalidae) and for Heteroxynema (Cavioxyura) viscaciae Sutton \& Hugot (Nematoda: Oxyuridae). The coprolites examined were tentatively attributed to Lagidium viscacia Molina (Mammalia, Rodentia, Caviomorpha, Chinchillidae). The life cycles of these parasites are discussed.

Key words: palaeoparasitology - Patagonia - rodent coprolites - Viscachataenia quadrata - Heteroxynema (Cavioxyura) viscaciae

The relevance of rodents as hosts in parasite life cycles, including those of zoonotic importance, has been fully recognised (Miyazaki 1991, Perkins et al. 2005, Morand et al. 2006). During the past few years, several samples of rodent coprolites and remains of rodents found in regurgitated pellets collected from several archaeological sites in Patagonia, Argentina, were examined for parasites. These samples span the Late Quaternary period, from the Pleistocene-Holocene Transition to the Late Holocene. Positive results were obtained for the nematodes Trichuris sp., Capillaria spp, Calodium sp., Eucoleus sp., Echinocoleus sp., Trichosomoides sp., Pterygodermatites sp., Paraspidodera sp. and Heteroxynema sp. and for Monoecocestus sp. and one taeniid (cestodes) (Fugassa 2006a, b, Fugassa \& Barberena 2006, Fugassa et al. 2007, Sardella \& Fugassa 2009a, b, 2011, Sardella et al. 2010, Beltrame et al. 2011).

Recently, new research was initiated at Cueva Huenul 1 (CH1) (36 56'45”S 6947’32”W), northern Neuquén (Patagonia, Argentina) (Fig. 1), an archaeological cave that provides a stratified sedimentary sequence ranging from the Late Pleistocene to the Late Holocene and in which well-preserved coprolites were found. The excavations provided a 1.4-m sequence composed of two sets

Financial support: UNMdP (EXA 525/10), CONICET (PIP 090/11), PICT Bicentenario (1856/10),PICT (1576/08) (ANPCyT)

+ Corresponding author: ornelabeltrame@hotmail.com

Received 25 August 2011

Accepted 7 December 2011 of lithostratigraphic units. Basal units VIII-V of the sequence have a high content of organic matter. This material is composed primarily of megafauna dung remains. The radiocarbon dates of these units range between $13.844 \pm 75-11.841 \pm 56$ years BP. In contrast, the second stratigraphic set (units IV-I) has a lower abundance of organic matter, with predominant aeolian sedimentation and is dated between $9.531 \pm 39-1.416 \pm 37$ years BP. The site presents evidence of a very brief, but redundant use of the cave by humans (Barberena et al. 2010) during different stages of the human settlement of northern Patagonia. This paper presents the first palaeoparasitological examination of the coprolites of CH1.

The aim of the present study was to examine the parasite fauna present in rodent coprolites collected from $\mathrm{CH} 1$ and to identify the parasitic remains and the host origin of the faeces to assess the parasite life cycles and the importance of rodents in the area studied. In conjunction with other analyses currently in progress, this study will contribute to a palaeoecological reconstruction of Patagonian ecosystems through time.

\section{MATERIALS AND METHODS}

Twenty rodent coprolites obtained from different units (II, V, VI and VII) of CH1 were examined for parasites. The coprolites were inventoried and processed individually (Fugassa 2006b). The examination, consisting of the external observation of the faeces, was conducted according to Chame (2003) and Jouy-Avantin (2003). Each coprolite was fully processed by rehydration in a $0.5 \%$ aqueous tris-sodium phosphate in a glass tube for one week at $4^{\circ} \mathrm{C}$, then homogenised and processed by spontaneous sedimentation (Lutz 1919, Callen \& Camer- 


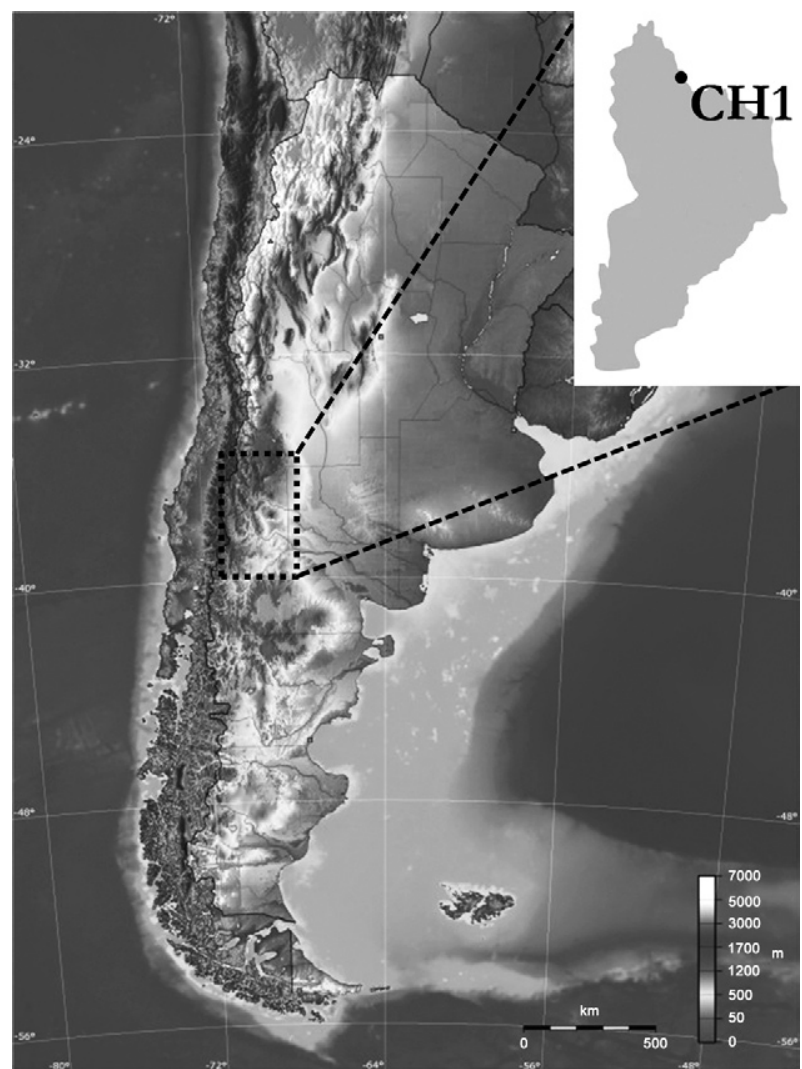

Fig. 1: geographic location of the archaeological site Cueva Huenul 1 (CH1), Northern Patagonia, Neuquén, Argentina. In detail, Neuquén Province, with the location of $\mathrm{CH}$ pointed.

on 1960) and preserved in $70 \%$ ethanol. Ten slides were prepared from each coprolite and one drop of glycerin was added to each slide. The slides were examined with light microscopy. The eggs of the parasites were measured and photographed at 40X magnification.

\section{RESULTS}

The coprolites were dark brown and concave to conical, with a smooth surface. One extreme was dull and the other was sharp (Fig. 2). The average measurements of the faeces were $11.70 \pm 1.88 \mathrm{~mm}$ long by $4.72 \pm 0.61 \mathrm{~mm}$ wide; the average weight was $0.10 \pm 0.03 \mathrm{~g}$.

Ten coprolites contained eggs of three parasites: 118 eggs of Heteroxynema (Cavioxyura) viscaciae Sutton \& Hugot 1988 (Nematoda: Oxyuridae), 32 eggs of Viscachataenia quadrata Denegri, Dopchiz, Elissondo \& Beveridge 2003 and eight eggs of Monoecocestus sp. Beddard 1914 (Cestoda: Anoplocephalidae).

The eggs of $H$. viscaciae (Fig. 3) were thick-walled with an operculum at 1 pole and were collected from two coprolites from unit II. The egg measurements $(\mathrm{n}=$ 90) ranged from $122.5-147.5(133.39 \pm 4.10) \mu \mathrm{m}$ long and 55.0-72.5 (62.75 \pm 4.48$) \mu \mathrm{m}$ wide. The eggs were oblong and asymmetrical with a convex side and a concave side, with a rounded pole and a more acute pole. An operculum was observed at the sharper pole.

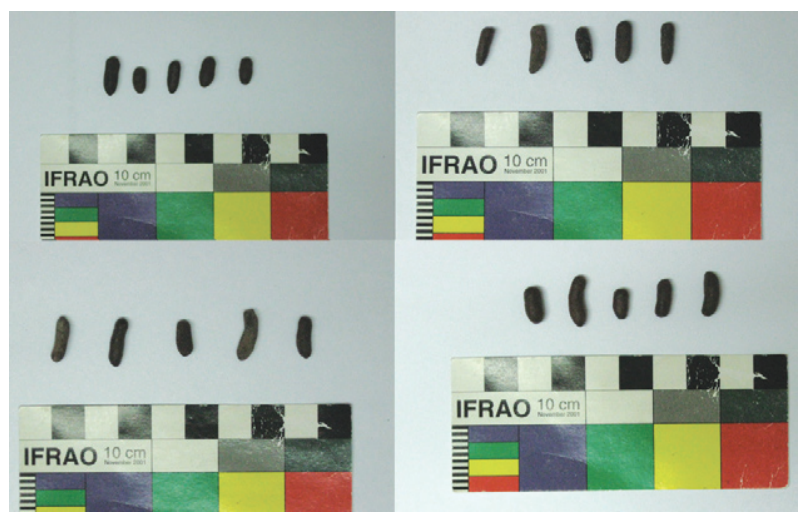

Fig. 2: macroscopic aspect of the rodent coprolites collected from the Cueva Huenul 1.

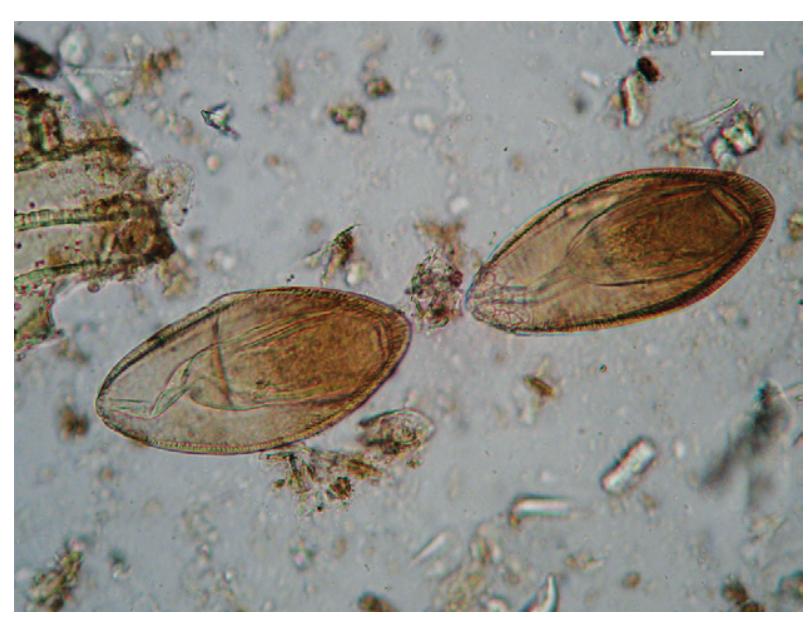

Fig. 3: egg of Heteroxynema (Cavioxyura) viscaciae (Nematoda: Oxyuridae). Bar $=20 \mu \mathrm{m}$.

Eggs of $V$. quadrata (Fig. 4) were collected from units VII, VI, V and II. These eggs were thick-shelled and fourlobed in shape. The oncosphere was not measured and was surrounded by an elongate pyriform apparatus $(n=3)$ $39.17 \mu \mathrm{m}$ long by $26.67 \mu \mathrm{m}$ wide. The size ranges (means) of the 13 eggs that were measured were 75-90 (82.69 \pm 5.44) $\mu \mathrm{m}$ long by $75-100(91.73 \pm 8.74) \mu \mathrm{m}$ wide.

A total of eight Cestoda eggs belonging to family Anoplocephalidae and with characteristics attributable to Monoecocestus sp. were collected from unit II (Fig. 5 ). The size ranges (means) of the four eggs that were measured were $54.5-60(59.15 \pm 1.3) \mu \mathrm{m}$ long by 52.5 $62.5(56.7 \pm 1.5) \mu \mathrm{m}$ wide.

The coprolites were tentatively assigned to Lagidium viscacia Molina 1782 (Caviomorpha: Chinchillidae), the chinchillón or vizcacha serrana.

\section{DISCUSSION}

Based on the characteristics of the eggs of the parasites found in this study and on knowledge regarding the parasite fauna of modern viscachas, the faeces were ten- 


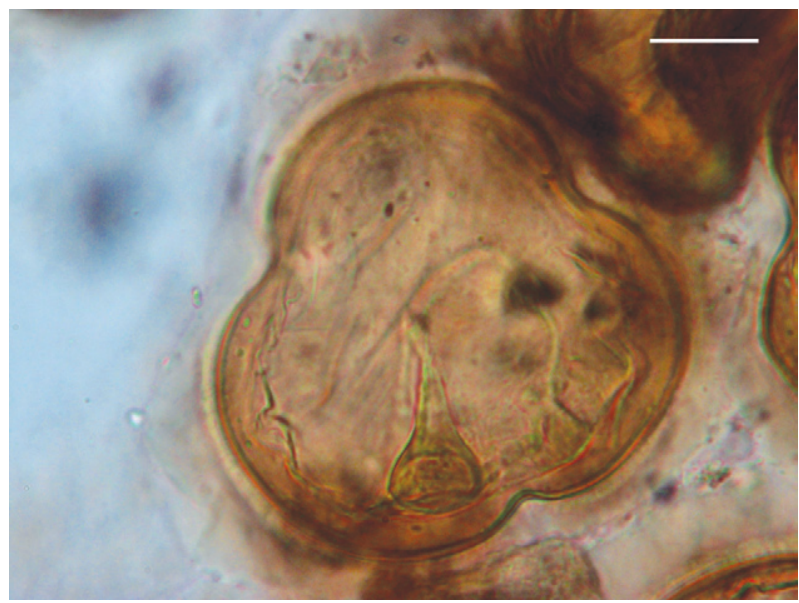

Fig. 4: egg of Viscachataenia quadrata (Cestoda: Anoplocephalidae). Bar $=20 \mu \mathrm{m}$.

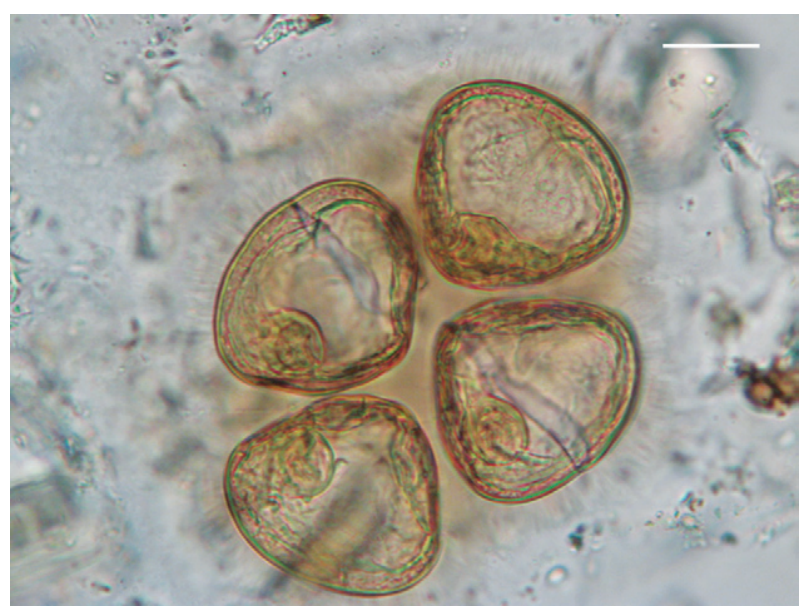

Fig. 5: egg of Monoecocestus sp. (Cestoda: Anoplocephalidae). Bar $=20 \mu \mathrm{m}$.

tatively attributed to L. viscacia (Caviomorpha: Chinchillidae) (Hugot \& Sutton 1989, Denegri et al. 2003).

The family Chinchillidae contains chinchillas, viscachas and their fossil relatives. The family is restricted to southern and western South America. Cabrera (1961) recognised three species of Lagidium, Lagidium peruanum, L. viscacia and Lagidium wolffsohni. The southern viscacha (L. viscacia) is found in Argentina, Bolivia, Chile and Peru. Reig (1986) stated that chinchillids predominate $(60 \%)$ among the living fauna of Andean localities and that Lagidium and Chinchilla are Andean endemics that became adapted to arid Andean valleys by the Miocene. $\mathrm{He}$ also reported that a foundational immigrant stock is known. The first representatives of this stock are well documented for the early Oligocene of Patagonia. These species originally occupied low lands and forested areas and secondarily invaded Andean zones. Viscacha bones were recovered in the archaeological faunal assemblage of $\mathrm{CH} 1$ in low frequencies. These animals may have been brought to the cave as food by humans occupying the site, but the bones do not show cuts that would verify this use. Viscachas may also have occupied the cave (their occurrence was recorded during the field work).

The anoplocephaline cestodes (Cyclophyllidea: Anoplocephalidae) represent a diverse group of parasites infecting both terrestrial mammals (placentals and marsupials) and birds. Based on the number of genera present in these hosts, the most important radiation of anoplocephalines has been in rodents and lagomorphs (Beveridge 1994, Wickström et al. 2005). The intermediate hosts of these cestodes are oribatid mites, which are ingested by their herbivorous definitive hosts (Beveridge 1994). Anoplocephalids are parasites of zoonotic importance for animals and humans (Denegri et al. 1998, Taylor et al. 2001).

Two species of anoplocephalid cestodes have previously been described in viscachas belonging to Lagidium Meyen (Rodentia: Chinchillidae) from South America. These anoplocephalid species are Cittotaenia quadrata von Linstow, 1904 and Cittotaenia pectinata Goeze, 1782, parasites of Lagidium peruanum and L. viscacia, respectively. V. quadrata Denegri, Dopchiz, Elissondo \& Beveridge, 2003 was subsequently proposed to accomodate C. quadrata (Denegri et al. 2003). Tantaleán et al. (2009) stated that in addition to the specimens of $C$. quadrata von Linstow 1904, the parasites of L. peruanum must also be recognised as $V$. quadrata. Denegri et al. (2003) hypothesised that the biogeographical relationships of the genus Viscachataenia suggest that it is derived from Monoecocestus, a genus that primarily parasitises South American rodents by duplication of the genitalia.

The eggs of $V$. quadrata, as found in $\mathrm{CH} 1$, were previously recorded in living $L$. viscaciae collected in Argentina and Peru (Denegri et al. 2003, Tantaleán et al. 2009).

Palaeoparasitological occurrences of anoplocephalid cestodes were previously reported for different archaeological sites in Patagonia. Eggs of Monoecocestus $\mathrm{sp}$. were found in rodent coprolites from Alero Mazquiarán (Sardella \& Fugassa 2009a) and from Alero Destacamento Guardaparque (Sardella et al. 2010). The eggs of Monoecocestus sp. observed in $\mathrm{CH} 1$ resemble those previously found in Holocenic samples from Patagonia. The presence of eggs attributable to V. quadrata and Monoecocestus sp. adds the $\mathrm{CH} 1$ cave, located northwest of the locations of previous findings, to the record of anoplocephalids in Patagonia.

The oxyurid nematodes include monoxenic parasites that live in the posterior third of the digestive tract of various vertebrates and arthropods (Anderson 2000). The family Heteroxynematidae includes nematodes that evolved in sciuromorph, caviomorph and myomorph mammals. In addition, this family includes the primitive Heteroxynema sp. suggested by Hall (1916) for Heteroxynema cucullatum, a parasite of the rodent Eutamias amoenus operarius from North America. This nematode genus was subsequently divided into three subgenera, with Cavioxyura spp as parasites of Neotropical Caviomorpha (Petter \& Quentin 1976).

In Argentina, Teixeira de Freitas and Lins de Almeida (1936) reported the presence of Heteroxynema werneckii in the intestine of the caviid Galea leucoblephara from the northern area of Jujuy Province. $H$. (C.) visca- 
ciae was described by Sutton and Hugot (1989) from $L$. viscaciae collected from Chubut Province. Foster et al. (2002) and Ferreira et al. (2007) confirmed the presence of this parasite in wild viscacha Lagostomus maximus from La Pampa and Chaco Provinces.

Heteroxynema sp. was recently found in rodent coprolites collected from Cerro Casa de Piedra, Santa Cruz Province, Argentina (Sardella \& Fugassa 2011). Based on the morphological characteristics and measurements of both the coprolites and the eggs found in $\mathrm{CH} 1$, the oxyurids found at the $\mathrm{CH} 1$ and Cerro Casa de Piedra archaeological sites, separated by $c a .1 .500 \mathrm{~km}$, were attributed to two different species, Heteroxynema sp. and $H$. viscaciae, respectively. Hugot and Sutton (1989) stated that the species related most closely to $H$. viscaciae is Heteroxynema (Cavioxyura) chiliensis Quentin, 1975, a parasite of Octodon degus (Molina) from Chile.

Perkins et al. (2005) stated that rodents represent one of the most important sources of zoonoses for mammals and that increases in the population densities of rodents resulted in the dispersal of zoonoses and brought them into closer contact with humans. The oxyurid nematodes found in this study are not presently considered zoonotic. However, anoplocephalids can cause human disease if people eat mites found in the soil (Denegri et al. 1998). It is probable that humans living in $\mathrm{CH} 1$ were exposed to $V$. quadrata and/or to Monoecocestus sp. during the time period considered because the earliest human presence in $\mathrm{CH} 1$ is considered to have occurred after approximately 10.000 years BP. The anoplocephalids are known to be accidental causative agents of human illness (Denegri et al. 1998, Taylor et al. 2001). Despite the brevity of the human use of the cave (Barberena et al. 2010), huntergatherers and animals could have been exposed to parasitic zoonoses and anthroponoses.

\section{ACKNOWLEDGEMENTS}

To Nora Vázquez (municipalidad de Buta Ranquil), Estela Cúneo and Liliana Martínez (Secretaría de Patrimonio, Neuquén Province), for their contribution to the development of the project.

\section{REFERENCES}

Anderson RC 2000. Nematode parasites of vertebrates: their development and transmission, CAB International, Wallingford, $650 \mathrm{pp}$.

Barberena R, Pompei MP, Otaola C, Neme G, Gil A, Borrazzo K, Durán V, Hoguin R 2010. Pleistocene-Holocene transition in northern Patagonia: evidence from Huenul Cave (Neuquén, Argentina). Curr Res Pleistocene 27: 5-7.

Beltrame MO, Fugassa MH, Sardella NH, Civalero MT, Aschero C 2011. Raptor pellets as zooarchaeological material for paleoparasitological studies in Patagonia. J Archaeol Sci 38: 1511-1515.

Beveridge I 1994. Family Anoplocephalidae Cholodkovsky, 1902. In LF Khalil, A Jones, RA Bray, Key to the cestode parasites of vertebrates, CAB International, Wallingford, p. 315-366.

Cabrera A 1961. Catálogo de los mamíferos de América del Sur. Rev Mus Arg Ciencias Nat Bernardino Rivadavia 4: 309-732.

Callen EO, Cameron TWM 1960. A prehistoric diet revealed in coprolites. New Scientist 8: 35-40.

Chame M 2003. Terrestrial mammal feces: a morphometric summary and description. Mem Inst Oswaldo Cruz 98 (Suppl. I): 71-94.
Denegri G, Dopchiz MC, Elissondo MC, Beveridge I 2003. Viscachataenia n.g. with the redescription of $V$. quadrata (von Linstow, 1904) n. comb. (Cestoda: Anoplocephalidae) in Lagidium viscacia (Rodentia: Chinchillidae) from Argentina. Sys Parasitol 54: 81-88.

Denegri G, Wilbert B, Pérez-Serrano J, Rodriguez-Caabeiro F 1998. Anplocephalid cestodes of veterinary and medical significance: a review. Fol Parasitol 45: 1-8.

Ferreira H, Uhart MM, Romano MC, Beldoménico PM, Samartino L, Paolicchi F, Lauricella M, Jorge MC, Schettino A, Guida N, Martín AM 2007. Inmovilización química y evaluación de salud de vizcachas salvajes (Lagostomus maximus) en el Chaco árido argentino. Arq Cs Vet Zool Unipar 10: 91-99.

Foster GW, Branch LC, Marchiote M, Kinsella JM, Villarreal D, Forrester DJ 2002. Gastrointestinal helminths of the plains vizcacha (Lagostomus maximus) from Argentina with observations on interspecific interactions between nematodes and cestodes. Comp Parasitol 69: 26-32.

Fugassa MH 2006a. Enteroparasitosis en poblaciones CazadorasRecolectoras de Patagonia Austral, PhD Thesis, Universidad Nacional de Mar del Plata, Mar del Plata, 276 pp.

Fugassa MH 2006b. Examen paleoparasitológico de sedimentos de un sitio arqueológico, Río Mayo, Chubut, Argentina. Parasitol Latinoam 61: 172-175.

Fugassa MH, Barberena R 2006. Cuevas y zoonosis antiguas: paleoparasitología del sitio Orejas de Burro 1 (Santa Cruz, Argentina). Magallania 34: 57-62.

Fugassa MH, Sardella NH, Denegri GM 2007. Paleoparasitological analysis of a raptor pellet from Southern Patagonia. J Parasitol 93: 421-422.

Hall MC 1916. Nematode parasites of mammals of the orders Rodentia, Lagomorpha and Hyracoidea. Proc US Nat Mus 50: 1-258.

Hugot JP, Sutton CA 1989. Contribution à la connaissance de la faune parasitaire d' Argentine, XV. Etude morphologique de Heteroxynema (Cavioxyura) viscaciae n. sp. (Nematoda: Heteroxynematidae) parasite de Lagidium viscacia boxi (Mammalia: Rodentia). Syst Parasitol 13: 111-120.

Jouy-Avantin F 2003. A standarized method for the description and study of coprolites. J Archaeol Sci 30: 367-372.

Lutz A 1919. O Schistosomum mansoni e a schistosomatose, segundo observações feitas no Brasil. Mem Inst Oswaldo Cruz 11: 121-155.

Miyazaki I 1991. An illustrated book of helminthic zoonoses, International Medical Foundation of Japan City, Tokio, 494 pp.

Morand S, Krasnov B, Poulin R, Degen A 2006. Micromammals and macroparasites: who is who and how they interact? In $\mathrm{S}$ Morand, BR Krasnov, R Poulin, Micromammals and macroparasites. From evolutionary ecology to management, SpringerVerlag, Tokyo, p. 3-9.

Perkins SE, Cattadori I, Hudson PJ 2005. The role of mammals in emerging zoonoses. Mamm Stud 30 (Suppl.): S67-S71.

Petter AJ, Quentin J-C 1976. Keys to the genera of the Oxyuroidea. In RC Anderson, AG Chabaud, S Willmott, CIH keys to the nematode parasites of vertebrates, CABI, Wallingford, p. 1-30.

Reig OA 1986. Diversity patterns and differentiation of high Andean rodents. In F Vuilleumier, M Monasterio, High altitude tropical biogeography, Oxford University Press, New York, p. 404-438.

Sardella NH, Fugassa MH 2009a. Parasites in rodent coprolites from the historical archaeological site Alero Mazquiarán, Chubut Province, Argentina. Mem Inst Oswaldo Cruz 104: 37-42. 
Sardella NH, Fugassa MH 2009b. Paleoparasitological analysis of rodent coprolites in holocenic samples from Patagonia, Argentina. J Parasitol 95: 646-651.

Sardella NH, Fugassa MH 2011. Paleoparasitological finding of eggs of nematodes in rodent coprolites dated at the early Holocene from the archaeological site Cerro Casa de Piedra 7, Santa Cruz, Argentina. J Parasitol 97: 1184-1187.

Sardella NH, Fugassa MH, Rindel DD, Goñi RA 2010. Paleoparasitological results for rodent coprolites from Santa Cruz Province, Argentina. Mem Inst Oswaldo Cruz 105: 33-40.

Tantaleán M, Sánchez L, Salízar P 2009. Viscachataenia quadrata
Denegri, Dopchiz, Elissondo \& Beveridge, 2003 (Cestoda: Anoplocephalidae) in Perú. Rev Peru Biol 16: 129-130.

Taylor LH, Latham SM, Woolhouse MEJ 2001. Risk factors for human disease emergence. Phil Trans R Soc Lond 356: 983-989.

Teixeira de Freitas JF, Lins de Almeida J 1936. Segunda contribuição ao conhecimento da fauna helminthologica da Argentina: Heteroxynema wernecki $\mathrm{n}$. sp. Mem Inst Oswaldo Cruz 31: 185-193.

Wickström LM, Haukisalmi V, Varis S, Hantula J, Henttonen H 2005. Molecular phylogeny and systematics of anoplocephalinae cestodes in rodents and lagomorphs. Sys Parasitol 62: 83-99. 